ks. Janusz Wilk ${ }^{1}$

0000-0002-6488-527X

Katowice

\title{
Psalm 91 (90) w pismach św. Elżbiety od Trójcy Świętej
}

Biblia dla Elżbiety od Trójcy Świętej ${ }^{2}$ stanowiła fundament duchowości. W pismach, które pozostawiła ${ }^{3}$, wyraźne widoczny jest jej osobowy kontakt ze słowem Bożym oraz pełna harmonia pomiędzy osobistym doświadczeniem Boga a spotkaniem z Nim w Piśmie Świętym ${ }^{4}$. Wielokrotnie cytowała lub parafrazowała biblijne teksty, chociaż w klasztornej

1 Ks. Janusz Wilk - ur. w 1973 roku; prezbiter archidiecezji katowickiej, dr hab. teologii w zakresie biblistyki. Publikacje książkowe z ostatnich lat: Listy Pasterskie. Pierwszy List do Tymoteusza, Drugi List do Tymoteusza, List do Tytusa. Wstęp, przekład z oryginału, komentarz (Katowice 2018); List do Filipian. Wstęp, przekład z oryginału, komentarz (Katowice 2017); Charakterystyka i zadania przełożonego wspólnoty chrześcijańskiej według Listów Pasterskich. Studium biblijno-pragmatyczne (Katowice 2015); Kapłan jako dobry żołnierz Chrystusa Jezusa. Aspekt biblijno-pastoralny (Katowice 2013). Redaktor naukowy serii Biblia Impulsy. E-mail: januszwilk@ katowice.opoka.org.pl.

2 Elżbieta Catez, ur. 18 lipca 1880 roku we Francji. Do Karmelu w Dijon wstąpiła 2 sierpnia 1901 roku. Zmarła na nieuleczalną wówczas chorobę Addisona 9 listopada 1906 roku. Została beatyfikowana 25 listopada 1984 roku, a kanonizowana - 16 października 2016 roku.

3 Zob. Élisabeth de la Trinité, CEuvres Complètes, édition critique C. De Meester, Paris $2017^{3}$. Wydanie polskie: Elżbieta od Trójcy Świętej, Pisma wszystkie, t. 1: Listy młodzieńcze, t. 2: Listy z Karmelu, t. 3: Pisma pomniejsze, przekł. i oprac. J.E. Bielecki, Kraków 2006.

4 Por. A. Borrell, Elisabetta della Trinità e la Bibbia, „Rivista di Vita Spirituale” 67 (2013) nr 4/5, s. 437. 
celi nie dysponowała pełnym przekładem Starego i Nowego Testamentu. Korzystała z Manuel du chrétien. Nouveau Testament. Psaumes. Imitation ${ }^{5}$. Występujące w jej pismach cytaty lub nawiązania do Starego Testamentu zostały zaczerpnięte z lektur oraz ksiąg liturgicznych. Brak dostępu do pełnego wydania Biblii wiązał się z ówczesną sytuacją religijno-społeczną. W praktyce Stary Testament był niedostępny dla ogółu wiernych, a Nowy był traktowany głównie jako zbiór (źródło) argumentów w polemice z przeciwnikami'.

Siostra Elżbieta systematycznie karmiła swoją wiarę słowem Bożym. Pokarmem tym dzieliła się również z rozmówcami, którzy w wyznaczonym czasie, precyzyjnie określonym przez zakonną regułę, mogli ją odwiedzać w rozmównicy Karmelu w Dijon. Najważniejszym jednak świadectwem jej kontaktu ze słowem Bożym są jej pisma. Ze zrozumiałych dla nas względów Mistyczka z Dijon najczęściej odnosiła się do tekstów Nowego Testamentu? ${ }^{7}$. Stary Testament nie był jednak dla niej obcy. Zwłaszcza Księga Psalmów stanowiła nie tylko jej codzienną modlitwę Liturgią Godzin, ale była również częstą jej towarzyszką podczas pisania listów, jak i innych pism ${ }^{8}$. W sumie siostra Elżbieta nawiązała w nich do 48 psalmów. Najczęściej cytowała lub parafrazowała Psalm $91(90)^{9}$.

5 Manuel du chrétien. Nouveau Testament. Psaumes. Imitation (Podręcznik chrześcijanina. Nowy Testament. Psalmy. O naśladowaniu Chrystusa), Gaume et Cie Éditeurs, París 1896. Układ książki: NT: ss. 1041 + Psalmy: ss. 214 + O naśladowaniu: ss. 214 - zob. A. Borrell, Elisabetta della Trinità e la Bibbia..., s. 441, przyp. 11; P.-M. Févotte, Aimer la Bible avec Élisabeth de la Trinité, Paris 1991, s. 38.

6 Por. T. M. Dąbek, Biblia w duchowości bt. Elżbiety od Trójcy Przenajświętszej, w: „Uwielbienie chwały”. VI Karmelitański Tydzień Duchowości z bł. Elżbietą od Trójcy Świętej. 5-8 maja 2003, red. J. W. Gogola, Kraków 2004, s. 39 (Karmel Żywy, 6).

7 W wykazie odnośników biblijnych sigle ST zajmują 52/3 strony, a sigle NT $12^{1 / 3}$ strony zob. Elżbieta od Trójcy Świętej, Pisma wszystkie, t. 3: Pisma pomniejsze..., dz. cyt., s. 475-492.

8 Na 120 odnośników do Księgi Psalmów, siostra Elżbieta najwięcej, bo 52 razy zastosowała ją w Listach (dalej: L), 48 razy w Ostatnich rekolekcjach (dalej: OR), 13 razy w Poezjach (dalej: P), 3 razy w Niebo w wierze (dalej: NW), 3 razy w Wielkość naszego powołania (dalej: WNP) i 1 raz w Zapiskach duchowych (dalej: ZD). Wszystkie skróty przyjęte za skrótami zastosowanymi w dziele Pisma wszystkie...

9 Wyliczamy 19 cytowań lub nawiązań do Ps 91 (90). W pismach Elżbiety od Trójcy Świętej występuje numeracja psalmów przyjęta za tłumaczeniem greckim (LXX). Obecnie (zasadniczo) przyjmuje się numerację za tekstem masoreckim (TM), co też stosujemy w naszym studium. Numeracja grecka zostaje podana w nawiasie. Zob. S. Łach (oprac.), J. Łach 
W całym jej twórczości literackiej wyraźnie wyróżnia się on na tle pozostałych psalmów ${ }^{10}$.

W niniejszym opracowaniu podejmujemy studium zainteresowania Elżbiety od Trójcy Świętej Psalmem 91 (90) oraz spróbujemy odnieść teologię tego psalmu do jej duchowości. Aby jak najlepiej zrozumieć percepcję tego psalmu przez Elżbietę, przeprowadzimy wpierw krótką jego egzegezę.

\section{Psalm $91(90)$}

\subsection{Propozycja przekładu Psalmu $91(90)^{11}$}

${ }^{1}$ Kto pozostaje w schronieniu u Najwyższego

i przebywa w cieniu Wszechmocnego,

${ }^{2}$ ten do Jahwe może mówić „moja Ucieczko i moja Twierdzo,

Boże mój, w Tobie pokładam mą ufność".

${ }^{3}$ On bowiem cię uwolni

z sideł zastawionych przez myśliwego

i od słowa ${ }^{12}$, co prowadzi do zniszczenia.

${ }^{4}$ On cię okryje swoimi piórami,

a pod jego skrzydłami znajdziesz schronienie.

Jego wierność jest jak pancerz i tarcza.

${ }^{5}$ Nie ulękniesz się niebezpieczeństwa nocy,

ani strzały wypuszczonej za dnia;

${ }^{6}$ ani zarazy, co błąka się w ciemnościach, ani epidemii, która unosi się w południe.

${ }^{7}$ Pomimo iż u twego boku padnie tysiąc

i dziesięć tysięcy po twojej prawicy -

do ciebie zło się nie zbliży.

${ }^{8}$ Swoimi oczami ujrzysz karę,

(przygotowanie do druku), Księga Psalmów. Wstęp, przekład z oryginału, komentarz, ekskursy, Poznań 1990, s. 40 (Pismo Święte Starego Testamentu, VII/2).

10 Drugi, najczęściej cytowany przez Elżbietę psalm, to Ps 19 (18) - 11 cytowań, a trzeci, to Ps 18 (17) - 9 cytowań.

11 Przekład własny na podstawie Biblia Hebraica Stuttgartensia, oprac. K. Elliger, W. Rudolph, H. P. Rüger, Stuttgart $1990^{4}$.

12 Tłumaczenie za wersjami starożytnymi. Dosłowne znaczenie słowa רֶּר to toaraza morowa". 
jaka spotka żyjących grzesznie.

${ }^{9}$ Jahwe bowiem jest twoją ucieczką ${ }^{13}$

i Najwyższego obrałeś sobie za obrońcę.

${ }^{10}$ Nie spotka cię żadne zło

i żadne schorzenie nie zbliży się do twojego namiotu,

${ }^{11}$ ponieważ polecił On swoim aniołom,

aby cię strzegli na wszystkich twoich drogach.

${ }^{12}$ Brać cię będą na swoje ręce,

abyś nie zranił swojej stopy o kamień.

${ }^{13}$ Po lwach i żmijach będziesz chodził, podepczesz młode lwy i smoki.

${ }^{14}$,Ponieważ przylgnął do mnie i poznał moje imię, wprowadzę go na bezpieczne miejsce na wysokości.

${ }^{15}$ Kiedy będzie mnie wzywał, odpowiem mu, będę z nim w niedoli, aby go uwolnić i uczynić sławnym.

${ }^{16}$ Obdarzę go długim życiem

i pozwolę mu cieszyć się zbawieniem".

\subsection{Struktura Psalmu}

Gdy spojrzymy całościowo na Ps 91 (90) dostrzeżemy, że jest to utwór dydaktyczny, powstały na bazie zaufania Bogu. Gdy przypatrzymy się poszczególnym jego wersetom zauważymy, że zawiera on zróżnicowane gatunki literackie: modlitwę chorego; modlitwę człowieka, któremu zagraża niebezpieczeństwo; pieśń umacniającą króla; liturgię świątynną; wykładnię mądrości. Jego koloryt liturgiczny wyraźnie jest widoczny dzięki zastosowaniu naprzemienności głosów, recytujących lub śpiewających poszczególne wersety. Na bazie tego kryterium możemy wyróżnić dwie części utworu: pierwsza z nich (wersety 1-13) przyjmuje formę pouczenia, a druga (wersety 14-16) - przemowy Boga.

Trzy wersety zaczynają się od partykuły ’ִ̣ (,zaiste”, ,doprawdy”, ,bo-

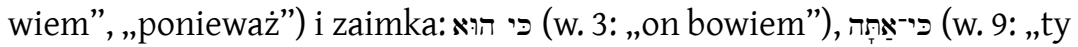
bowiem") בי בי בי (w. 14: ,ponieważ do mnie"). Tylko werset 2 zawiera czasownik związany z mówieniem (אֵַר). W pozostałych wersetach należy

13 Dosłownie: „Ponieważ Ty, Jahwe, jesteś moim schronieniem”. 
wydobyć osobę mówiącą z gry zaimków i dopełnień. W psalmie wyliczamy modlącego się (orant), nauczyciela lub kapłana przewodzącego liturgii (nauczyciel-kapłan) oraz Boga (Bóg). W tym kluczu proponujemy następujący schemat psalmu ${ }^{14}$ :

\begin{tabular}{|l|l|l|}
\hline \multicolumn{1}{|c|}{ WERSET(Y) } & \multicolumn{1}{|c|}{ PODMIOT } & \multicolumn{1}{c|}{ TREŚć } \\
\hline 1 & nauczyciel-kapłan & $\begin{array}{l}\text { Wypowiada się w trzeciej osobie lub interpelu- } \\
\text { je w wołaczu }\end{array}$ \\
\hline 2 & orant & Zwraca się do Boga: wyznanie wiary i ufności \\
\hline $3-4$ & nauczyciel-kapłan & Mówi do oranta na temat Boga: On cię obroni \\
\hline $5-8$ & nauczyciel-kapłan & Mówi do oranta o niebezpieczeństwach \\
\hline $9 a$ & orant & Zwraca się do Boga, powtarzając swoje wyznanie \\
\hline $9 b-13$ & nauczyciel-kapłan & Mówi do oranta o zagrożeniach i o ochronie \\
\hline $14-16$ & Bóg & Mówi do oranta \\
\hline
\end{tabular}

Według przedstawionego podziału ról, orant dwukrotnie wyznaje swoje zaufanie Bogu. Ciężar teologiczny całego utworu spoczywa jednak na nauczycielu-kapłanie, którego zadaniem jest wsparcie oranta. Na końcu psalmu (w. 14-16) słyszymy wyrocznię Boga, który nie zwraca się do oranta w drugiej osobie, lecz mówi o nim w trzeciej osobie. Przypuszcza się, że wspomniana osoba jest tożsama z postacią z początku psalmu. Może być ona reprezentantem całej modlącej się wspólnoty ${ }^{15}$.

Na strukturę Ps 91 (90) możemy również spojrzeć pod kątem doboru słownictwa oraz zakresu poruszanych tematów. W tym aspekcie dwa pierwsze wersety stanowią początek tematyczny, skoncentrowany

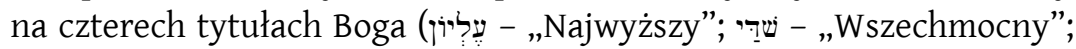

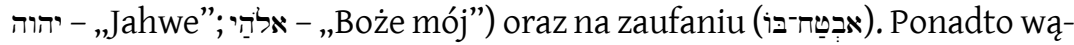
tek ucieczki (schronienia) występujący w dwóch pierwszych wersetach,

14 Por. L. Alonso Schökel, C. Cartniti, Salmos. Traducción, introducciones y comentario, Estella (Navarra) $2009^{4}$, t. 2, s. $1185-1186$.

15 Por. L. Alonso Schökel, C. Cartniti, Salmos. Traducción, introducciones y comentario, Estella (Navarra) $2009^{4}$, t. 2, s. 1186. 
pojawia się również w wersecie 9a. Ze względu na przejrzystą lekturę tekstu zmienia się w tłumaczeniu podmiot wypowiadający te słowa ${ }^{16}$, nie naruszając jednak teologicznego przekazu tego wersetu.

Po wprowadzeniu (w. 1-2) następują trzy strofy (w. 3-16). W pierwszej z nich (w. 3-8) orant językiem wywodzącym się z wokabularza łowiecko-militarnego opisuje zagrożenia. W drugiej (wersety 9-13) za pomocą słownictwa myśliwsko-teriomorficznego charakteryzuje otrzymaną opiekę. W strofie trzeciej (w. 14-16) spotykamy słownictwo soteriologiczne, bazujące na terminach zbawienia i wyzwolenia (פלט - „ocalić”; „uratować” [w. 14]; ישוּאעה - ,pomoc”, ,zbawienie”[w. 16]) oraz na dominującym zaimku pierwszej osoby (בִי - בִי - ponieważ do mnie" [w.14];

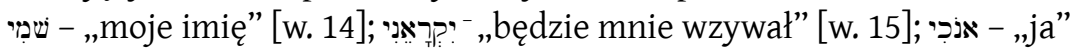

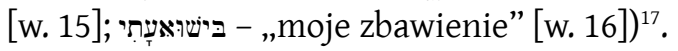

Pierwsze dwa wersety zawierają formułę zaproszenia (wstępu) do powierzenia się Bogu i zaufania Jemu. Strofy pierwsza i druga stanowią część dydaktyczną, a strofa trzecia - podsumowująca - otrzymała formę wyroczni, potwierdzającej wcześniejsze wersety. Tego rodzaju układ ma wspomóc oranta w jego zmaganiach i zagrożeniach. Wskazuje, gdzie znaleźć bezpieczeństwo (schronienie).

${ }_{16}$ W imieniu oranta („Ty, Jahwe, jesteś moim schronieniem”), wypowiada się nauczyciel-kapłan („Jahwe bowiem jest twoją ucieczką"). Zob. także aparat krytyczny: Biblia Hebraica Stuttgartensia..., ad locum. Przykłady tłumaczeń: Pismo Święte Starego i Nowego Testamentu. Najnowszy przekład z języków oryginalnych z komentarzem, oprac. Zespół Biblistów Polskich z inicjatywy Towarzystwa Świętego Pawła, Częstochowa 2009 (Biblia Paulistów): „Gdyż Pan jest twoim schronieniem!”; Pismo Święte Starego i Nowego Testamentu w przekładzie z języków oryginalnych, oprac. Zespół Biblistów Polskich z inicjatywy Benedyktynów Tynieckich, red. A. Jankowski, K. Romaniuk, L. Stachowiak, T. Hergesel, R. Rubinkiewicz, Poznań $2003^{5}$ (na nowo opracowane i poprawione: Biblia Tysiaclecia): „Albowiem Pan jest twoją ucieczką”; Pismo Święte Starego i Nowego Testamentu. „Biblia Warszawsko-Praska”, w przekładzie z języków oryginalnych oprac. K. Romaniuk, Warszawa 1997: „Pan jest schronieniem dla ciebie”; Die Bibel. Altes und Neues Testament. Einheitsübersetzung, Freiburg im Breisgau-Basel-Wien 1980: „Denn der Herr ist deine Zuflucht”. Przekład dosłowny proponuje np. La Sacra Bibbia. Conferenza Episcopale Italiana. Unione Editori e Librai Cattolici Italiani, Città del Vaticano 2008: „Sì, mio rifugio sei tu, o Signore!"

17 Por. G. Ravasi, Psalmy, przekł. K. Stopa, Kraków 2008, cz. 3 (Psalmy 72-103 /wybór), s. 353-355 (Zgłębiać Biblię). 


\subsection{Symbolika Psalmu}

Psalm 91 (90) w pierwszej części (w. 1-13) jest utworem dydaktycznym, a w drugiej (14-16) wyrocznią Boga. Język passusu pouczającego, to kompozycja symboli zaczerpniętych z kilku aspektów życia. Ich systematyzacja przedstawia się w następujący sposób ${ }^{18}$ :

\begin{tabular}{|c|c|c|}
\hline WERSET(Y) & OBRAZ & SYMBOL \\
\hline $1-2$ & mieszkanie, cień, twierdza & opieka, pokój, bezpieczeństwo \\
\hline 3 & $\begin{array}{l}\text { sidła myśliwego, zaraza } \\
\text { morowa }\end{array}$ & śmierć, zagłada \\
\hline 4 & $\begin{array}{l}\text { pióra, skrzydła, pancerz, } \\
\text { tarcza }\end{array}$ & ochrona, bezpieczeństwo, wierność \\
\hline $5 a$ & niebezpieczeństwa nocy & $\begin{array}{l}\text { bliżej nieokreślone niebezpieczeństwa, po- } \\
\text { cząwszy od nagłych ataków wroga, a skończyw- } \\
\text { szy na tajemniczym działaniu demonów }\end{array}$ \\
\hline $5 b$ & $\begin{array}{l}\text { strzała wypuszczona } \\
\text { za dnia }\end{array}$ & $\begin{array}{l}\text { niespodziewany najazd wroga, polowanie lub } \\
\text { choroba, która raptem dopada człowieka }\end{array}$ \\
\hline 6 & $\begin{array}{l}\text { zaraza w ciemnościach, } \\
\text { epidemia w południe }\end{array}$ & $\begin{array}{l}\text { wzrost i rozprzestrzenianie się zagrożeń w cza- } \\
\text { sie nocnego snu lub południowej drzemki (od- } \\
\text { poczynku) }\end{array}$ \\
\hline 7 & $\begin{array}{l}\text { tysiąc, dziesięć tysięcy za- } \\
\text { bitych }\end{array}$ & powszechnie tryumfująca śmierć \\
\hline 8 & $\begin{array}{l}\text { kara dla żyjących grzesz- } \\
\text { nie }\end{array}$ & odpłata, klęska bezbożnych \\
\hline 9 & schronienie, obrońca & opieka, pokój, bezpieczeństwo \\
\hline 10 & namiot & dom, ludzkie ciało \\
\hline $11 \mathrm{a}$ & anioł & przewodnik, opiekun, pomoc, wsparcie \\
\hline $11 \mathrm{~b}$ & droga & ludzkie postępowanie, życie człowieka \\
\hline $12 \mathrm{a}$ & ręka & działanie, pomoc, wsparcie \\
\hline $12 \mathrm{~b}$ & kamień & życiowe trudności, zatwardziałość serca \\
\hline
\end{tabular}

18 Opracowano na podstawie: J. Wilk, Psalm 91. O troskliwości Boga, „Apostolstwo Chorych" 6 (2012), s. 8-10; Słownik symboliki biblijnej. Obrazy, symbole, motywy, metafory, figury stylistyczne i gatunki literackie w Piśmie Świętym, red. L. Ryken, J. C. Wilhoit, T. Longman III, red. nauk. wyd. polskiego W. Chrostowski, przekł. Z. Kościuk, Warszawa 2003 (Prymasowska Seria Biblijna, 20); M. Lurker, Słownik obrazów i symboli biblijnych, przekł. K. Romaniuk, Poznań 1989. 


\begin{tabular}{|c|l|l|}
\hline WERSET(Y) & \multicolumn{1}{|c|}{ OBRAZ } & \multicolumn{1}{c|}{ SYMBOL } \\
\hline $13 a$ & lew & $\begin{array}{l}\text { gwałtowność, niszczaca siła, nieodparta moc, } \\
\text { otwarty atak (w innych tekstach posiada rów- } \\
\text { nież symbolikę pozytywną) }\end{array}$ \\
\hline $13 \mathrm{a}$ & żmija & $\begin{array}{l}\text { dwulicowość, przebiegłość, stałe zagrożenie, } \\
\text { podstępny atak }\end{array}$ \\
\hline $13 \mathrm{~b}$ & smok & siła, potęga, chaos \\
\hline
\end{tabular}

W pieśni wyraźnie uwidoczniona jest Boża opieka, wyrażona w dwóch przewodnich obrazach: ucieczki (schronienia) i drogi. Pierwszy z nich, odnoszący się do zamkniętego i chronionego miejsca (mieszkanie, cień, twierdza), nawiązywał do świątyni jerozolimskiej - miejsca ucieczki i azylu każdego Żyda, który lękał się o swoje życie. Pióra, skrzydła, pancerz, tarcza (w. 4), to metafora osobistej relacji z Bogiem. Obraz drugi (drogi), choć wydaje się przeciwstawny do pierwszego, stanowi jego uzupełnienie. Bóg jest obecny w miejscu schronienia (świątyni), a przez swoich posłańców (aniołów) jest również obecny na drogach ludzkiego życia ${ }^{19}$.

Cała gama symboli odzwierciedla realizm i różnorodność niebezpieczeństw zagrażających człowiekowi. Równocześnie ukazuje ochronę, jaką otrzymuje człowiek, który w Bogu pokłada nadzieję. Symbole te zawierają jednoznaczny komunikat - troska Boga o człowieka nie jest niczym ograniczona, albowiem zarówno miejsce, jak i czas nie stanowią dla Jahwe jakiejkolwiek przeszkody, która utrudniałaby lub uniemożliwiałaby stałą pieczę nad człowiekiem (zob. w. 5-6). Język symboli eksponuje również zatroskaną posługę aniołów o człowieka (zob. w. 11-13). Psalmista wszystkie te obrazy zastosował w jednym celu - aby wzmocnić człowieka w jego zaufaniu do Boga.

19 Por. L. Alonso Schökel, C. Cartniti, Salmos..., s. 1189; T. Lorenzin, I Salmi. Nuova versione, introduzione e commento, Milano 2008³ , s. 361 (I Libri Biblici. Primo Testamento, 20). 


\subsection{Teologia Psalmu}

Psalm 91 (90) ma potęgować ufność, wręcz przemieniać ją w pewność moralną, że Bóg nie tylko jest, ale i troszczy się o człowieka ${ }^{20}$. Przypomina o realizmie życia - zagrożeniach, zmaganiach i problemach podczas drogi ziemskiego życia, których nigdy nam nie zabraknie. Psalm ten jest jak towarzysz drogi, który nie tyle ostrzega o niebezpieczeństwach, co podpowiada o Bożej opiece. Pomaga przezwyciężyć paraliżujący strach, każde zwątpienie i wszystkie zagnieżdżające się w ludzkim umyśle wątpliwości ${ }^{21}$. Antidotum na nie stanowi wiara w Boga, rodząca zaufanie i wzmacniająca wytrwałość.

Droga życia, chociaż obciążona trudami i niebezpieczeństwami, gdy jest przemierzana pod Bożą opieką i wytyczana zgodnie z Bożymi wskazówkami (w. 14: przylgnięcie do Boga i poznanie Jego imienia), zawsze zaprowadzi do zbawienia - życia z Bogiem ${ }^{22}$.

\section{Percepcja Psalmu 91 (90) w pismach św. Elżbiety od Trójcy Świętej}

W żadnych ze swoich pism Elżbieta od Trójcy Świętej nie zapisała w całości Psalmu 91 (90). Posługiwała się pojedynczymi jego wersetami lub cytowała (parafrazowała) dwa-trzy wersety. Specyfikacja cytowań (parafraz) tego psalmu przedstawia się w następujący sposób ${ }^{23}$ :

20 Por. A. Klawek, Godzina biblijna. Psalm o Opatrzności Bożej (Ps 90), „,Ruch Biblijny i Liturgiczny" 19 (1966) nr 3, s. 200, https://doi.org/10.21906/rbl.3053.

${ }_{21}$ Por. M. E. Tate, Psalms 51-100, Dallas 2002, s. 459 (Word Biblical Commentary, 20).

22 Por. H. J. Kraus, Psalms 60-150, transl. by H.C. Oswald, Minneapolis 1993, s. 225 (A Continental Commentary).

${ }_{23}$ Por. Elżbieta od Trójcy Świętej, Pisma wszystkie, t. 3: Pisma pomniejsze..., dz. cyt., s. 478. W „wykazie odnośników biblijnych” znajdujemy 23 cytowania Ps 91 (90). Faktycznie jest ich 19, gdyż w „wykazie” rozdzielono wersety 10-11, a w rzeczywistości stanowią one jeden passus (chodzi o L 244). Nie rozdzielono natomiast tych wersetów w L 241 i 260. Rozdzielono również wersety 4.10.11 zawarte w WNP 13. 


\begin{tabular}{|l|l|}
\hline \multicolumn{1}{|c|}{ WERSET(Y) } & \\
\hline 1.4 .10 & L 242. \\
\hline 4 & L $197 ; 243 ; 244 ; 245 ; 249 ; 263 ; 312$. \\
\hline $4-6$ & OR 23. \\
\hline 4.10 .11 & WNP 13. \\
\hline 4.11 .12 & L $244 ;$ P 107. \\
\hline 10 & L 312. \\
\hline $10-11$ & L $241 ; 244 ; 260$ \\
\hline 11 & L $245 ; 249 ; 295$. \\
\hline
\end{tabular}

W cytowaniu lub parafrazowaniu myśli Ps 91 (90) dominuje werset 4 zjego przesłaniem o Bożej opiece. Podobną myśl przewodnią zawierają równie często przywoływane przez mniszkę wersety 10 i 11. Natomiast jeden raz nawiązała do wersetu 1 i 12, łącząc ich treść z innymi wersetami. Jeden też raz posłużyła się metaforycznym opisem niebezpieczeństw zagrażających człowiekowi (wersety 5-6).

\subsection{Listy}

Elżbieta od Trójcy Świętej, jak każda karmelitanka w Dijon, miała ograniczony dostęp do korespondencji ${ }^{24}$. Czas, który zgodnie z zakonną regułą mogła przeznaczać na pisanie listów, wykorzystywała bardzo mądrze. Uboga w środki pisarskie ${ }^{25}$, nie pozbawiała jednak swoich adresatów

24 Zob. Elżbieta od Trójcy Świętej, Pisma wszystkie, t. 3: Pisma pomniejsze..., dz. cyt., s. 471.

25 W celi karmelitanek tamtego okresu nie było ani biurka ani stolika. Wyposażenie celi siostry Elżbiety to: siennik, krzesło i pulpit z deski. Deska ta $(51 \mathrm{~cm} \mathrm{x} 34 \mathrm{~cm})$ była przymocowana do ściany, w rogu, na lewo od okna na wysokości $65 \mathrm{~cm}$. Mogła być używana jako stolik lub regał na książki. W celi siostry Elżbiety służyła ona jako regał na kilka książek. $\mathrm{W}$ drugim rogu, po prawej stronie okna, była przymocowana inna deska zaokrąglona (30 cm długości, na wysokości 1,35 m), na której stał dzbanek z wodą - podręczna „umywalka”. „Pulpitem”, na którym Mistyczka zapisywała swoje teksty była mała skrzynka drewniana (44 cm x $26 \mathrm{~cm}$ x $7 \mathrm{~cm}$ ), w której można było przechowywać niektóre osobiste pisma i dokumenty. Kładąc ją na kolana, stanowiła podstawę pod materiał piśmienniczy - zob. L 89; L 169 wraz z przyp. 7; G. Pesenti, Santa Elisabetta della Trinità, Torino 2016, s. 30 (Messaggeri d'amore, 511). Więcej o pisaniu listów w Karmelu i piśmie Elżbiety od Trójcy Świętej zob. 
myśli pełnych wiary, miłości, a czasem zatroskania. Treść Psalmu 91 (90) doskonale odzwierciedla jej wiarę i zaufanie. W jedenastu swoich listach bezpośrednio odniosła się do tego psalmu.

Najczęściej cytowanym lub parafrazowanym w listach wersetem jest werset 4. Obraz schronienia się pod Bożymi skrzydłami będzie stosować samodzielnie lub łączyć go z innymi metaforami zawartymi w tym psalmie. Korzysta z niego, by zapewnić, że nowo narodzoną siostrzenicę (również Elżbietę $e^{26}$ ) chce osłaniać dwoma skrzydłami - modlitwą i ofia$\mathrm{rą}^{27}$. Gdy rodzi się druga jej siostrzenica (Odette), pisze do obydwu, zapewniając je o swojej modlitwie, aby Boży cień okrywał je i by Bóg strzegł je od wszelkiego zła ${ }^{28}$. W myśli tej łączy przesłanie wersetów 1, 4 i 10. Kilka dni po liście do siostrzenic, 17 sierpnia 1905 roku pisze do chorej Antoniny Bobet, życząc jej, aby Bóg strzegł ją w cieniu swych skrzydeł ${ }^{29}$. Dzień później przesyła swojej przyjaciółce Iwonie de Rostang - zawiarającej 24 sierpnia 1905 roku związek małżeński - list, w którym jako życzenia cytuje między innymi Ps 91 (90), 4. 10-11. Swoją czytelniczkę wprowadza w słowa psalmu („Psalmista pewnego dnia śpiewał pod natchnieniem Ducha Świętego") ${ }^{30}$, a po ich zapisaniu nawiązuje jeszcze do wersetu 12, by Iwona na drogach życia była noszona przez aniołów ${ }^{31}$.

Po miesięcznej przerwie mniszka z Dijon przygotowała kolejny list, tym razem wspólny do swojej matki oraz rodzonej siostry. W kontekście otrzymanych zdjęć siostrzenic i refleksji o „małych Chevignardkach” oraz ich mamie, zapewnia całą swoją rodzinę o szczególnej bliskości i o modlitwie, w której prosi Boga, aby Jego aniołowie okrywali ją swymi skrzydłami i strzegli w ciągu drogi życia ${ }^{32}$. Zdanie to zostało oparte na wersetach 4 i 11 Psalmu 91 (90).

Wprowadzenie ogólne, w: Elżbieta od Trójcy Świętej, Pisma wszystkie, t. 1: Listy młodzieńcze, dz. cyt., s. 86-103.

\footnotetext{
26 Urodzona 11 marca 1904 roku. W tym dniu został też napisany ten list.

Zob. L 197 - Do matki.

Zob. L 242 - Do siostrzenic Elżbiety i Odette Chevignard.

Zob. L 243 - Do pani Bobet.

30 L 244 - Do Iwony de Rostang.

31 Zob. L 244 - Do Iwony de Rostang.

32 Por. L 245 - Do matki.
} 
Myślą zaczerpniętą z tych samych wersetów (4 i 11), Elżbieta od Trójcy Świętej zakończyła list do Marii Luizy de Sourdon - przyjaciółki, u której niegdyś spędzała wakacje ${ }^{33}$. Dziękuje w nim za czekoladki, które otrzymała od Marii Luizy z okazji imienin (18 listopada 1905) ${ }^{34}$.

Radość i wdzięczność z różańca, którym siostra Elżbieta została obdarowana przez Antoninę de Bobet, była bezpośrednią przyczyną napisania do niej kolejnego listu. Antonina zakupiła go dla swojej przyjaciółki podczas pielgrzymki do Lourdes (18-19 sierpnia 1905). Został jej przekazany za pośrednictwem cioci Antonini, pani de Vathaire. Elżbieta dziękuje za „tak piękny różaniec”35. W drugiej części listu porusza kwestie zamieszkania Boga w najgłębszym centrum jej duszy oraz słabości (choroby) Antoniny. Dotykając zwłaszcza ostatniego zagadnienia, pozostawia swojej przyjaciółce myśli z dwóch psalmów: Ps 44 (43), 4-5 oraz Ps 91 (90), 1. 4. Zapewnia ją ponownie, że Bóg okrywa ją swoim cieniem $^{36}$.

W każdym z tych listów przywoływany Ps 91 (90) odzwierciedla głębokie przekonanie Elżbiety od Trójcy Świętej o Bożej opiece nad adresatkami jej listów. Modli się w intencjach adresatek i równocześnie utwierdza je w zaufaniu do Boga, który w swojej opatrzności stale troszczy się o człowieka.

\section{2. „Wielkość naszego powołania”}

Ostatni list Elżbiety od Trójcy Świętej, w którym występuje metafora skrzydeł, to list datowany na około 9 września 1906 roku. Dla mistyczki z Dijon był to czas pobytu w klasztornej infirmerii ${ }^{37}$ i bezpośredniego przygotowania na spotkanie z Umiłowanym w „niebieskiej ojczyźnie”

33 Zob. ich wspólną fotografię w: Błogosławiona Elżbieta od Trójcy Świętej. O świcie Ciebie szukam. Wspomnienie pewnego oblicza i pewnego serca, red. P. P. Furdzik, Kraków 2006, nr 20, s. 49 .

$34 \quad$ L 249 - Marii Luizy de Sourdon.

35 Zob. fotografie Siostry Elżbiety z tym różańcem oraz sam różaniec - Elżbieta od Trójcy Świętej. O świcie Ciebie szukam..., dz. cyt., nr 59 i 170, s. 146.

${ }^{36}$ L 263 - Do pani de Bobet.

37 Siostra Elżbieta zamieszkała w niej w drugiej połowie marca 1906 roku i pozostała tam do 9 listopada 1906 roku, czyli do dnia swojej śmierci. 
(Flp 3, 20). Fizycznie wyczerpana, wręcz „w krańcowej słabości”, pisze jeszcze list do Franciszki de Sourdon ${ }^{38}$. Otrzymał on formę „,małego traktatu", który przez francuskiego wydawcę został zatytułowany La grandeur de notre vocation (Wielkość naszego powołania) ${ }^{39}$. Elżbieta wyjaśnia w nim „ukochanemu dziecku”"40, czym jest pokora, umieranie samemu sobie, co to jest wolność, jakim zagrożeniem jest pycha. Zatrzymuje się nad zagadnieniem idealnego życia duszy i wkorzenienia w Chrystusa. Mobilizuje adresatkę do mocnej wiary i wzrastania w dziękczynieniu. Całość kończy zdaniem: „Niech w cieniu Jego [Boga] skrzydeł On cię strzeże od wszelkiego zła". Zostało ono zaczerpnięte z Ps 91 (90), 4. 10. 11. Elżbieta kończy ostatnie pismo do Franciszki de Sourdon metaforą pełną nadziei i zaufania. Z tym pozostawia swoją „Malinkę”.

\subsection{Poezje}

W zbiorze pism, jakie pozostały po Elżbiecie Catez - Elżbiecie od Trójcy Świętej, bogatą grupę stanowią utwory poetyckie. Pierwszy zachowany wiersz pochodzi z maja 1894 roku, ostatni z 22 października 1906 roku. Elżbieta „pisze swoje wiersze - z bardzo małymi wyjątkami - dla nikogo poza sobą i ze względu na Jezusa"41. Intensyfikują one jej modlitwę, stanowią medytację misterium Chrystusa, wznoszą myśl ku Maryi,

38 Franciszka de Sourdon (ur. 25 VI 1887 r.) była córką hrabiny Małgorzaty de Sourdon - wiernej przyjaciółki Marii Catez - matki Elżbiety. Była dzieckiem oraz nastolatką bardzo żywotną, wręcz nadpobudliwą. Obdarzona przez Elżbietę przyjaźnią, w ciągu ośmiu lat otrzymała od niej 26 listów. Starsza o siedem lat Elżbieta nadała tej przyjaźni pewien aspekt macierzyński. Gdy wstąpiła do Karmelu nazywała siebie „mateczką” Franciszki (np. L 99; 129), często też z czułością przekształcała jej imię Franciszka na „Malinka” (np. L 272; 312).

39 List ten, który w wydaniu francuskim otrzymał nr 310, a w przekładzie polskim nr 312, zarówno w wydaniu francuskim, jak i polskim jest tylko zasygnalizowany w zbiorze listów. W całości został on opublikowany w odrębnym zbiorze pism Elżbiety, zatytułowanym Utwory duchowe - zob. Élisabeth de la Trinité, Euvres Complètes..., dz. cyt., s. 133-139; Elżbieta od Trójcy Świętej, Pisma wszystkie, t. 3: Pisma pomniejsze..., s. 380-388.

40 WNP $1 ; 6$.

${ }^{41}$ Wprowadzenie do poezji, w: Elżbieta od Trójcy Świętej, Pisma wszystkie, t. 3: Pisma pomniejsze..., s. 9. 
odzwierciedlają wydarzenia związane z życiem karmelitańskiej wspólnoty. Zawsze wypływają z głębi jej serca ${ }^{42}$.

Podobnie jak w innych pismach, tak również w swoich poezjach Elżbieta nawiązuje do Księgi Psalmów. W sumie trzynaście razy odniosła się do psalmów; z czego jeden raz do Ps 91 (90). Uczyniła to w wierszu dedykowanym siostrze Marii Józefie - młodej postulantce, której Elżbieta od Trójcy Świętej była „aniołem” (zakonnym opiekunem) ${ }^{43}$. Utwór ten został datowany przez samą autorkę na dzień 29 lipca 1906 roku, czyli na liturgiczne wspomnienie św. Marty. W Karmelu święta ta jest patronką sióstr nie-chórzystek. Do tej właśnie grupy należała siostra Maria Józefa.

Pierwsza część tego utworu powstała na podstawie wiersza napisanego rok wcześniej do rodzonej siostry Elżbiety - Małgorzaty ${ }^{44}$. Pieśń ta opiewa tajemnicę bogactwa duszy zamieszkanej przez Boga; tajemnicę wybrania oraz stałej obecności Stwórcy w duszy stworzenia. Druga jego część wyraźnie nawiązuje do zdrowotnej sytuacji Elżbiety (pobytu w infirmerii) i jej przygotowań do spotkania z Oblubieńcem w Jego Światłości. Siostra Elżbieta zapewnia swoją młodą podopieczną, że również w „Światłości, gdzie moje Mieszkanie”, nie pozostawi ją samą. Gdy znajdzie się „w Ognisku, gdzie wieczne kochanie”, okryje ją wtedy swymi skrzydłami i strzec będzie jej kroków, aż po sam kres drogi, by przypadkiem nie potknęła się jej stopa na ziemi.

Elżbieta od Trójcy Świętej pełniąca wówczas misję zakonnego anioła wobec postulantki, bezpośrednio odnosi się do Ps 91 (90), 4. 11. 12. Czerpie z niego myśli dotyczące Bożej opieki i zadań aniołów. Dzieli się nimi z postulantką. Maria Józefa oprócz anioła stróża, otrzyma jeszcze jednego „anioła” - Elżbietę od Trójcy Świętej. Dla młodej mniszki śmierć siostry Elżbiety nie będzie oznaczać utraty opiekunki.

${ }^{42}$ Por. R. Moretti, Introduzione a Elisabetta della Trinità. Vita - scritti - dottrina, Roma 1984, s. 92.

43 P 107 - Czy zgłębiłaś przepaść Miłości?

${ }_{44}$ P $94-C z y$ znasz dobrze swoje bogactwo? 


\section{4. „Ostatnie rekolekcje”}

Ostatnie rekolekcje to pismo przygotowane na wyraźną prośbę przeoryszy - matki Germany od Jezusa, która była świadoma, że już niebawem będzie zobowiązana do przygotowania nekrologicznego Okólnika o siostrze Elżbiecie od Trójcy Świętej ${ }^{45}$. Notatki mistyczki z Dijon z osobistych rekolekcji przeżywanych od 16 do 31 sierpnia 1906 roku w klasztornej infirmerii, miały nie tylko pomóc przeoryszy w opracowaniu zwyczajowego pisma o zmarłej karmelitance, ale przede wszystkim miały być świadectwem jej kończącego się życia ${ }^{46}$.

Przemyślenia rekolektantki zapisane w Ostatnich rekolekcjach są bardzo mocno osadzone w tekstach biblijnych ${ }^{47}$. Dominują passusy Apostoła Pawła i psalmy. Siostra Elżbieta odwołuje się do 28 psalmów, 48 razy nawiązując do ich wersetów. Myśl Ps 91 (90) została wykorzystana 1 raz. Karmelitanka odniosła się do wersetów 4-6, w których znajduje się pełna bezpieczeństwa metafora skrzydeł (w. 4) oraz gdzie zostały wymienione niebezpieczeństwa zagrażające człowiekowi (strach nocny, strzały lecącej wśród dnia, zła wślizgującego się w mrokach, napaść czarta południowego ${ }^{48}$ [w. 5-6]. W całym swoim piśmiennictwie mniszka z Dijon tylko jeden raz skorzystała z negatywnej symboliki wersetów 5-6.

45 Por. Wprowadzenie do „Ostatnich rekolekcji”, w: Elżbieta od Trójcy Świętej, Pisma wszystkie, t. 3: Pisma pomniejsze..., s. 391-392; M. M. Philipon, Trójca Święta w moim życiu. Doktryna duchowa Siostry Elżbiety od Trójcy Przenajświętszej, przekł. Siostra dominikanka z klasztoru św. Anny i siostra benedyktynka od nieustającej adoracji, Poznań $2002^{2}$, s. 101.

46 W późniejszym, szerszym opracowaniu życia Elżbiety od Trójcy Świętej, matka Germana tak określiła notes z Ostatnimi rekolekcjami: „Stronnice te zapisane w ciągu bezsennych nocy, wśród okropnych boleści, na pierwszy rzut oka zdają się być tylko prostem echem ustępów Pisma św., zaopatrzonych uwagami osobistemi; w rzeczywistości jednak są czemś więcej: Siostra Elżbieta powiedziała kiedyś Matce Przeoryszy, że w tym zbiorku starała się wytłumaczyć, jak pojmowała swoje zadanie, jako Chwały sławy [Laudem gloriae - przyp. autora] i jak, w jej rozumieniu, można już tu na ziemi żyć życiem niebiańskim; jest to myśl przewodnia jej ostatnich Rekolekcyj, jak również całego jej życia zakonnego" - Germana od Jezusa, Wspomnienia. Siostra Elżbieta od Trójcy Świętej, Karmelitanka bosa (1880-1906), przekł. A. Gmurowski, Lwów 1932, s. 238 (w cytacie zachowano pisownię tłumacza).

${ }_{47}$ Zob. ich specyfikację: Wprowadzenie do Ostatnich rekolekcji, w: Elżbieta od Trójcy Świętej, Pisma wszystkie, t. 3: Pisma pomniejsze..., dz. cyt., s. 401, przyp. 29.

${ }_{48}$ Na podstawie Wulgaty - zob. Biblia Sacra iuxta vulgatam versionem, oprac. B. Fischer, I. Gribomont, H. F. G. Sparks, W. Thiele i inni, Stuttgart 1994, ad locum. 
Elżbieta od Trójcy Świętej koncept Ps 91 (90), 4-6 zamieściła w notatkach z dziewiątego dnia rekolekcji (24 sierpnia), kiedy rozważała wezwanie do świętości (zob. Kpł 11, 44-45; 1 P 1, 16). Droga ta („obecności Bożej”) zawsze wiedzie naprzód, „nigdy nie wiedząc, co to jest odwrót” ${ }^{49}$. Mistyczka jest realistką. Wie, że w ziemskim wędrowaniu nigdy nie zabraknie zmagań i zagrożeń, dlatego nawiązuje do ich symbolicznego opisu w Ps 91 (90), 5-6. Dusza krocząc jednak „sama z Samym”, cały czas znajduje się pod opieką Bożych skrzydeł (Ps 91 [90], 4).

\section{Podsumowanie}

Psalm 91 (90) zachęca do zaufania Bogu. Przypomina, że pośród życiowych trudów i niebezpieczeństw człowiek nigdy nie jest sam. Jest przy nim Bóg, są Jego aniołowie. Uwydatnia on jednak warunek, który w pełni umożliwia Bożą opiekę, a jest nim osobiste pragnienie tej opieki (w. 1-2) oraz mocne i wytrwałe przylgnięcie do Pana (w. 14). Zażyłość człowieka z Bogiem pozwala Mu konstruktywnie towarzyszyć człowiekowi w jego wędrowaniu przez życie. Ostatecznie pełna wiary i ufności więź z Bogiem, swoje dopełnienie znajdzie u celu tej drogi w „niebieskiej ojczyźnie" (Flp 3, 20).

Sądząc po ilości bezpośrednich lub pośrednich nawiązań Elżbiety od Trójcy Świętej do Psalmu 91 (90), możemy stwierdzić, że zajmował on szczególnie miejsce w jej duchowości. Karmelitanka żyjąc w głębokiej i miłosnej zażyłości z Bogiem, który zamieszkiwał w jej duszy, urzeczywistniała teologię tego psalmu (zaufanie, wierne trwanie przy Bogu). Więź ta dawała jej poczucie bezpieczeństwa i duchowy pokój, pomimo przeżywanych cierpień. Wiedziała, że stale jest przy niej Ten, który potrafi wybawić człowieka z każdego zagrożenia. Dała temu wyraz w Ostatnich rekolekcjach (nr 23). To jedyny tekst z Ps 91 (90) adresowany „do niej samej”, chociaż pisany z polecenia przeoryszy. Analizując lokalizację tego psalmu w innych tekstach, dostrzegamy jego cytowanie 
lub parafrazowanie w pismach adresowanych do osób bliskich jej sercu. Przywołując ten utwór, dzieliła się z nimi swoją pewnością o Bożej opiece, co szczególnie uwydatnia wielokrotnie stosowana metafora skrzydeł $\mathrm{z}$ wersetu 4. Drugim obrazem przekazywanym adresatom jej pism jest zapewnienie o opiece aniołów. To przesłanie, zawarte w wersetach 11-12, zamieszczone jest w kontekście zła, z którym człowiekowi przychodzi się zmagać w codziennym życiu (w. 10).

Karmelitanka obficie czerpała z treści Psalmu 91 (90). Wybór poszczególnych jego wersetów może odzwierciedlać jej wypełnione pokojem i zaufaniem spojrzenie na rzeczywistość własnego życia. Wiedziała jak wiele trudu i zmartwień towarzyszy ludzkiemu istnieniu. Niejednokrotnie dawała tego wyraz w swoich pismach. Nigdy ich nie banalizowała. Jednakże swoich adresatów uwrażliwiała na stałą obecność Boga i Jego aniołów przy człowieku. Pisała im o tym, odwołując się do własnego doświadczenia. Karmiła ich bowiem tym, czym sama żyła: zjednoczeniem z Bogiem, świadomością Jego opieki, skupieniem, prostotą w postrzeganiu ludzkiego życia, które rozpoczęte na ziemi swoje dopełnienie znajdzie w „Światłości, gdzie nasze Mieszkanie”.

Obecność Boga i Jego aniołów przy człowieku umacnia nadzieję i rodzi wytrwałość. Nawet, jeśli w życiu nie wszystko jest tak, jakby się chciało, żeby było. 


\section{Summary}

\section{Psalm 91 (90) w pismach św. Elżbiety od Trójcy Świętej}

W artykule podjęto analizę percepcji Psalmu 91 (90) w pismach Elżbiety od Trójcy Świętej (1880-1906). W pierwszej części studium zaproponowano własny przekład Psalmu 91 (90) oraz przeprowadzono jego krótką egzegezę (struktura; symbolika; teologia). W części drugiej dokonano analizy pism, w których Elżbieta od Trójcy Świętej wykorzystała przesłanie Psalmu 91 (90). Ten najczęściej cytowany lub parafrazowany przez karmelitankę z Dijon psalm, odzwierciedlał jej zażyłość z Bogiem oraz poczucie bezpieczeństwa i pokoju. Tym też dzieliła się z adresatami swoich pism.

Słowa kluczowe: Elżbieta od Trójcy Świętej; Psalm 91 (90); Boża opieka; wiara; nadzieja

\section{The Psalm 91 (90) in the Letters of St. Elisabeth of the Holy Trinity}

In the article is analyzed the perception of the Psalm 91 (90) in the Elisabeth's of the Holy Trinity (1880-1906) writings. In the first part of the study is offered own translation of the Psalm 91 (90) and is done its short exegesis (structure; symbolism; theology). In the second part is made an analysis of the writings in which Elisabeth of the Holy Trinity used the message of the Psalm 91 (90). This most frequently quoted or paraphrased psalm by Carmelite from Dijon, reflected her intimacy with God and feeling of peace and safety. And this is what she shared with audience of her writings.

Keywords: Elisabeth of the Holy Trinity; Psalm 91 (90); God's care; faith; hope

Transl. by Patrycja Tomaszewska

\section{Bibliografia}

\section{Psalm $91(90)$}

Biblia Hebraica Stuttgartensia, oprac. K. Elliger, W. Rudolph, H. P. Rüger, Stuttgart $1990^{4}$.

Biblia Sacra iuxta vulgatam versionem, oprac. B. Fischer, I. Gribomont, H. F. G. Sparks, W. Thiele i in., Stuttgart $1994^{4}$.

Die Bibel. Altes und Neues Testament. Einheitsübersetzung, Freiburg im BreisgauBasel-Wien 1980.

Pismo Święte Starego i Nowego Testamentu. „Biblia Warszawsko-Praska”, przekł. z języków oryginalnych oprac. K. Romaniuk, Warszawa 1997. 
Pismo Święte Starego i Nowego Testamentu. Najnowszy przekład z języków oryginalnych $z$ komentarzem, oprac. Zespół Biblistów Polskich z inicjatywy Towarzystwa Świętego Pawła, Częstochowa 2009 (Biblia Paulistów).

Pismo Święte Starego i Nowego Testamentu w przekładzie zjęzyków oryginalnych, oprac. Zespół Biblistów Polskich z inicjatywy Benedyktynów Tynieckich, red. A. Jankowski, K. Romaniuk, L. Stachowiak, T. Hergesel, R. Rubinkiewicz, Poznań $2003^{5}$ (na nowo oprac. i poprawione: Biblia Tysiąclecia).

La Sacra Bibbia. Conferenza Episcopale Italiana. Unione Editori e Librai Cattolici Italiani, Città del Vaticano 2008.

Alonso Schökel L., Cartniti C., Salmos. Traducción, introducciones y comentario, Estella (Navarra) 20094, t. 2 (Verbo Divino).

Klawek A., Godzina biblijna. Psalm o Opatrzności Bożej (Ps 90), „Ruch Biblijny i Liturgiczny" 19 (1966) nr 3, s. 198-202, https://doi.org/10.21906/rbl.3053.

Kraus H.J., Psalms 60-150, transl. by H.C. Oswald, Minneapolis 1993 (A Continental Commentary).

Lorenzin T., I Salmi. Nuova versione, introduzione e commento, Milano $2008^{3}$ (I Libri Biblici. Primo Testamento, 20).

Lurker M., Słownik obrazów i symboli biblijnych, przekł. K. Romaniuk, Poznań 1989.

Księga Psalmów. Wstęp, przekład z oryginału, komentarz, ekskursy, oprac. Łach S., przygotowanie do druku Łach J., Poznań 1990 (Pismo Święte Starego Testamentu, VII/2).

Ravasi G., Psalmy. Psalmy 72-103 (wybór), cz. 3, przekł. K. Stopa, Kraków 2008 (Zgłębiać Biblię).

Tate M. E., Psalms 51-100, Dallas 2002 (Word Biblical Commentary, 20).

Stownik symboliki biblijnej. Obrazy, symbole, motywy, metafory, figury stylistyczne i gatunki literackie w Piśmie Świętym, red. L. Ryken, J. C. Wilhoit, T. Longman III, red. nauk. wyd. polskiego W. Chrostowski, przekł. Z. Kościuk, Warszawa 2003 (Prymasowska Seria Biblijna, 20).

Wilk J., Psalm 91. O troskliwości Boga, „Apostolstwo Chorych” 6 (2012), s. 8-10.

\section{Elżbieta od Trójcy Świętej}

Élisabeth de la Trinité, CEuvres Complètes, édition critique C. De Meester, Paris $2017^{3}$. Wydanie polskie: Elżbieta od Trójcy Świętej, Pisma wszystkie, t. 1: Listy młodzieńcze; t. 2: Listy z Karmelu; t. 3: Pisma pomniejsze, przekł. i oprac. J. E. Bielecki, Kraków 2006.

Borrell A., Elisabetta della Trinità e la Bibbia, „Rivista di Vita Spirituale” 67 (2013) nr 4/5, s. 437-469.

Dąbek T. M., Biblia w duchowości bł. Elżbiety od Trójcy Przenajświętszej, w: „Uwielbienie chwały”. VI Karmelitański Tydzień Duchowości z bł. Elżbietą od Trójcy Świętej, 5-8 maja 2003, red. J. W. Gogola, Kraków 2004, s. 33-49 (Karmel Żywy, 6).

Elżbieta od Trójcy Świętej. O świcie Ciebie szukam. Wspomnienie pewnego oblicza i pewnego serca, red. P. P. Furdzik, Kraków 2006.

Févotte P.-M., Aimer la Bible avec Élisabeth de la Trinité, Paris 1991. 
Germana od Jezusa, Wspomnienia. Siostra Elżbieta od Trójcy Świętej. Karmelitanka bosa (1880-1906), przekł. A. Gmurowski, Lwów 1932.

Philipon M. M., Trójca Święta w moim życiu. Doktryna duchowa Siostry Elżbiety od Trójcy Przenajświętszej, przekł. siostra dominikanka z klasztoru św. Anny i siostra benedyktynka od nieustającej adoracji, Poznań $2002^{2}$.

Manuel du chrétien. Nouveau Testament. Psaumes. Imitation, París 1896.

Moretti R., Introduzione a Elisabetta della Trinità. Vita - scritti - dottrina, Roma 1984.

Pesenti G., Santa Elisabetta della Trinità, Torino 2016 (Messaggeri d'amore, 511). 